\title{
EVALUATION OF SOME SALIVARY ENZYMES AS A DIAGNOSTIC BIOMARKER FOR PROGRESSION OF PERIODONTAL DISEASE
}

\author{
Khaled El-Asklany Abdel Kader ${ }^{1}$, Mohamed Ismail Assadawy², Samy Mostafa Elhabbak ${ }^{3}$
}

\begin{abstract}
Objectives: Saliva has been discussed lately as an important biological material to the purpose of diagnosis. The objective of our present study, was to study candidate biochemical markers, enzymes, in salivary samples for the screening of periodontal disease. These enzymes were ALT, AST, GGT, LDH and CK. Subjects and Methods: A total of sixty participants males and females and ranging in age from 30-45 years old were selected; 40 patients with periodontal disease and 20 healthy individuals were included in this study. Group I was comprised of 20 patients having periodontitis; forming the test group. Group II was comprised of 20 patients with gingivitis, forming the positive control group. Group III was comprised of 20 healthy adult volunteers who represented the negative control group. All individuals were assessed by: Gingival index (Loe and Sillness), probing depth and clinical attachment loss. Patients within periodontitis group underwent conventional periodontal treatment consisting of oral hygiene instructions, full mouth thorough scaling and root planning (SRP). The salivary samples were collected at baseline from all groups (before treatment) and three weeks post treatment of periodontitis group. Results: The activities of ALT, AST, GGT, LDH and CK enzymes were significantly increased in the saliva of patients with periodontal disease in relation to those of healthy condition, thus they can be used as a biological biomarker for progression of periodontal disease. This is probably a consequence of pathological processes in periodontal tissues where from these intracellular enzymes are increasingly released into the secretion which surrounds them - saliva. There was also an established correlation between AST and the value of the gingival index and probing depth. After periodontal treatment the activity of examined salivary enzymes was decreased, which is probably a result of periodontal tissues repair. Conclusion: Screening of periodontal disease by measuring salivary levels of ALT, AST, GGT, LDH and CK may be a feasible, simple and convenient approach that does not require expert examiners especially in mass screening events.
\end{abstract}

KEYWORDS: Periodontitis, markers, enzymes, ALT, AST, GGT, CK, LDH, saliva.

\section{INTRODUCTION}

The term 'periodontal disease' encompasses a wide range of chronic inflammatory conditions of the gingiva, alveolar bone and periodontal ligaments which support the teeth. Periodontal disease always begins with gingivitis, the localized inflammation of the gingiva that is initiated by bacteria located in the dental plaque, which is a microbial biofilm that forms on the teeth ${ }^{(1)}$.

Current clinical assessments used to determine periodontal disease severity, response to therapy and disease activity include: pocket depth,

1. B.D.S (2013), Faculty of Oral and Dental Medicine, Mansoura University, Dentist at Ministry of Health

2. Lecturer of Oral Medicine, Periodontology, Diagnosis and Oral Radiology. Faculty of Dental Medicine, (Boys - Cairo), Al-Azhar University

3. Professor of Oral Medicine, Periodontology, Diagnosis and Oral Radiology. Faculty of Dental Medicine, (Boys - Cairo), Al-Azhar University 
clinical attachment level, bleeding upon probing, gingival inflammation, plaque presence or level of oral-hygiene care, suppuration and radiographic bone loss.An important caveat of periodontal disease diagnosis is that only after the biologic onset of the disease process will clinical assessments provide a diagnosis of periodontal disease ${ }^{(2,3)}$. In addition, measurement errors, such as probing angulation and force, can interfere with accurate measurements of attachment level and can be significant enough to distort clinical treatment planning ${ }^{(4,5)}$.These clinical measurements are helpful for assessment, but alone are unable to determine current disease activity or future risk of structure loss ${ }^{(6)}$. They also need a trained dentist or periodontist to apply.

Nowadays new technologies are becoming available that are capable of measuring combinations of inflammatory cy tokines, enzymes and proteinases for rapid chair-side testing. Utilizing saliva to identify and measure specific phenotypes and hostderived mediators will allow highly individualized diagnosis, prognosis and treatments for periodontal diseases. This personalized medicine approach will strengthen the power of the clinical oral examination and medical history assessments, providing patients with evidence-based, targeted risk care ${ }^{(7)}$.

Another advantage of using saliva as a 'real time' diagnostic specimen is the fact that it can be collected in a comfortable manner. Unlike a blood draw and the associated fear of the needle, or a urine sample and the intrusion of privacy, saliva can be collected in a non-invasive manner. Deviations in salivary production and flow rates can be influenced by factors such as time of day, duration of collection time, temperature, hydration status of the individual, systemic health status and emotional state of the person. Despite these potential limitations, the analysis of biomarkers in saliva has been shown for disease detection, monitoring and compliance with treatment recommendations, in both medicine and dentistry ${ }^{(8)}$.
The aim of the study was to detect the interrelationship between some salivary enzymes; namely: Alanine aminotransferase (ALT), aspartate aminotransferase (AST), gamma-glutamyl transferase (GGT), lactate dehydrogenase (LDH) and creatine kinase (CK); and the activity of periodontal disease.

\section{SUBJECTS AND METHODS}

\section{Study setting and population}

A total of sixty participants males and females and ranging in age from 30-45 years old were selected; 40 patients with periodontal disease and 20 healthy individuals were included in this study from the outpatient clinic of the Department of Oral Medicine, Periodontology, Diagnosis and Oral Radiology in the Faculty of Dental Medicine (Boys - Cairo), Al-Azhar University.

\section{Ethical consideration}

Research procedures and values were explained to all subjects and they signed an informal consent.

\section{Inclusion criteria}

Subjects were selected and randomly divided into 3 equal groups. They were matched for age and gender as possible. Group I: It was comprised of 20 patients having periodontitis; forming the test group. (Underwent phase I therapy). Group II: It was comprised of 20 patients with gingivitis, forming the positive control group. Group III: It was comprised of 20 healthy adult volunteers who represent the negative control group.

\section{Exclusion Criteria}

We have excluded subjects who were suffering from any systemic diseases, individuals with history of smoking or alcohol abuse, pregnant and lactating women, subjects who had taken antibiotics in the last 6 months and those who had received periodontal treatment in the last 6 months. 


\section{Preoperative assessment}

All individuals were assessed by: Gingival index (Loe and Sillness) ${ }^{(9)}$, probing depth and clinical attachment loss. Patients with at least four teeth with $\geq 5 \mathrm{~mm}$ clinical attachment loss, were categorized as the periodontitis group.

\section{Intervention}

Patients within periodontitis group underwent conventional periodontal treatment consisting of oral hygiene instructions, full mouth thorough scaling and root planning (SRP). The salivary samples were collected from all groups at baseline (before treatment) and three weeks post treatment of periodontitis group, (Figure 1).

\section{Postoperative assessment}

Patients were monitored clinically concerning clinical signs and symptoms, attachment level and periodontal pocket depth, followed by sample collection.

\section{Sample collection}

Each participant was asked to rinse with $15 \mathrm{ml}$ of water (to wash out exfoliated cells) and then asked to chew paraffin wax for five minutes. The stimulated saliva $(10 \mathrm{ml})$ of the patient was collected in a sterile test tube. The salivary samples were transported in an ice bag to the 'Regional Center of Mycology and Biotechnology, Al-Azhar university', in which samples were stored in $-80^{\circ} \mathrm{C}$ until all samples were collected , then the activities of the following salivary enzymes were determined spectrophotometrically, with the help of an autoanalyzer: ALT, AST, GGT, LDH and CK.

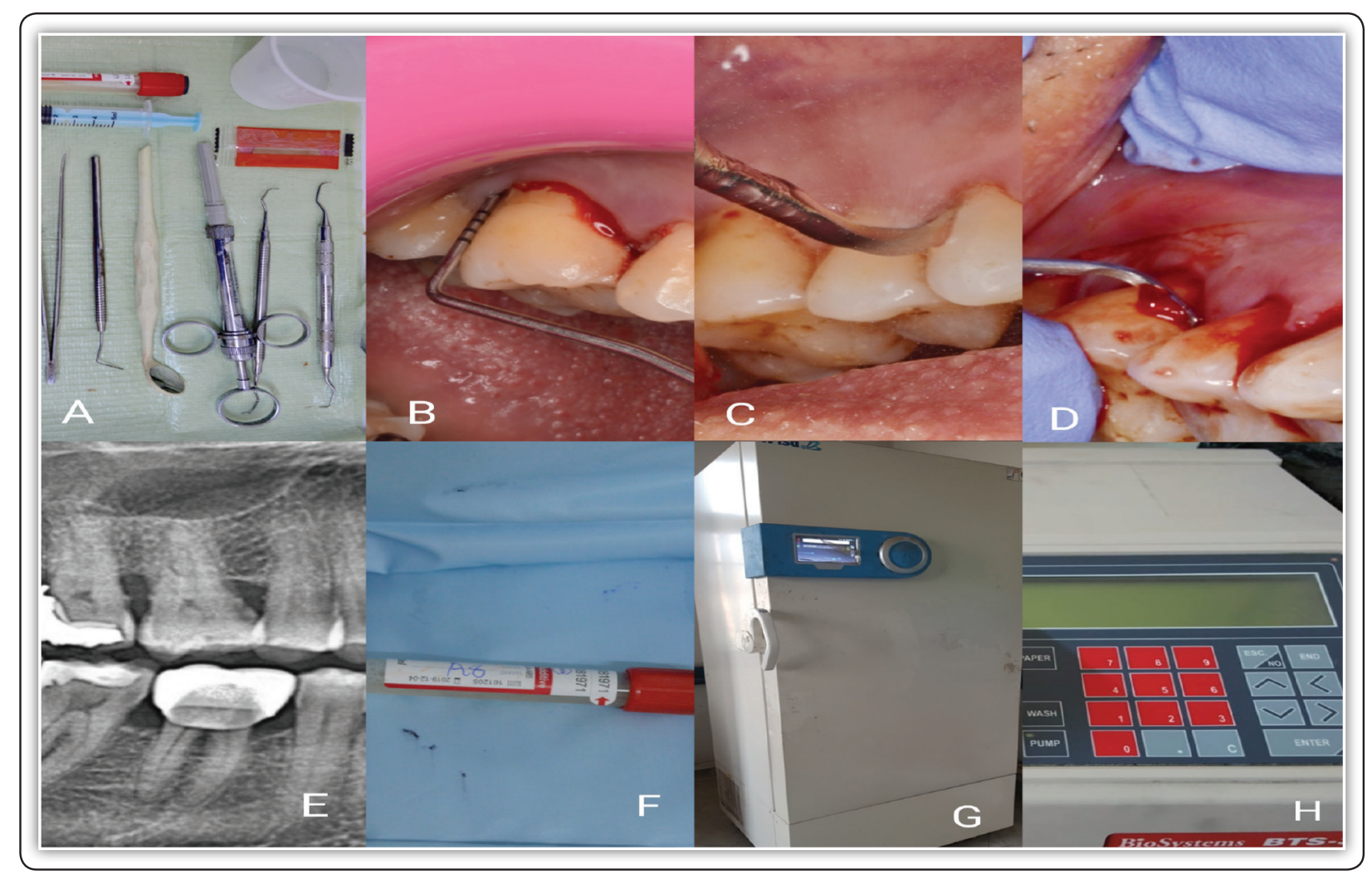

FIG (1) a; Armamentarium used, b; Preoperative photo showing initial situation of a periodontal pocket, c; Full mouth scaling done by means of ultrasonic scaler, d; Full mouth root planing, e; X-ray showing bone resorption, f; Sample collection and storage temporarily in ice pack, $\mathrm{g}$; Transport of samples for storage in very cold temperature $-80^{\circ} \mathrm{C}, \mathrm{h}$; Spectrophotometry by autoanalyzer. 


\section{Data management}

Data was collected and statistically analyzed by applying suitable statistical tests.

\section{RESULTS}

- The obtained results have shown that the activity of examined enzymes in saliva of the patients with periodontal disease was significantly higher in relation to the control groups. The established differences showed the statistical significance of a high level $(\mathrm{p}<0.001)$.

- A correlation was checked between gingival index and probing depth with other enzymes in periodontitis group before and after treatment. There was a positive correlation between AST and 'Gingival index and Probing depth' before treatment and after treatment. As the Gingival index and Probing depth increased, AST increased and when Gingival index and Probing depth decreased, AST decreased.

\section{AST}

TABLE (1A) Summarizes descriptive statistics of AST in each studied group. Healthy group showed mean of 52.95 \pm 13.39 while Gingivitis group showed $101.80 \pm 41.25$ and Periodontitis group showed $195.35 \pm 46.86$ before treatment and $62.10 \pm 23.83$ after treatment. (All enzymes measures are by unit/liter.)

\begin{tabular}{|c|c|c|c|c|c|c|}
\hline \multirow{3}{*}{ Groups } & \multirow{3}{*}{$\mathrm{N}$} & \multicolumn{5}{|c|}{ AST } \\
\hline & & \multirow{2}{*}{ Min. } & \multirow{2}{*}{ Max. } & \multirow{2}{*}{ Mean \pm SD } & \multicolumn{2}{|c|}{$95 \% \mathrm{CI}$} \\
\hline & & & & & LL & UL \\
\hline \multicolumn{2}{|l|}{ Healthy $(\mathrm{n}=20)$} & 34.0 & 79.0 & $52.95 \pm 13.39$ & 46.68 & 59.22 \\
\hline \multicolumn{2}{|l|}{ Gingivitis $(\mathrm{n}=20)$} & 30.0 & 194.0 & $101.80 \pm 41.25$ & 82.50 & 121.10 \\
\hline \multirow{2}{*}{ Periodontitis $(n=20)$} & Before & 134.0 & 305.0 & $195.35 \pm 46.86$ & 173.42 & 217.28 \\
\hline & After & 22.0 & 96.0 & $62.10 \pm 23.83$ & 50.95 & 73.25 \\
\hline
\end{tabular}

TABLE (1B) Summarizes comparison between the three groups according to AST: there was a statistically significant difference in mean AST in the three groups. Periodontitis group showed mean AST 195.35 \pm 46.86

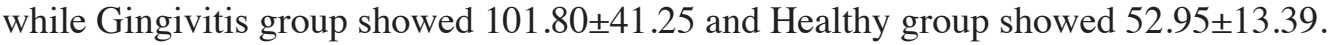

\begin{tabular}{|c|c|c|c|c|c|}
\hline & $\begin{array}{l}\text { Healthy } \\
(n=20)\end{array}$ & $\begin{array}{l}\text { Gingivitis } \\
(\mathbf{n}=\mathbf{2 0})\end{array}$ & $\begin{array}{l}\text { Periodontitis (Before) } \\
\qquad(\mathrm{n}=\mathbf{2 0})\end{array}$ & $\mathbf{F}$ & $\mathbf{P}$ \\
\hline AST & $52.95 \pm 13.39$ & $101.80 \pm 41.25$ & $195.35 \pm 46.86$ & $77.064^{*}$ & $<0.001^{*}$ \\
\hline Sig. bet. grps & & $<0.001^{*}, \mathrm{p}_{2}<0.00$ & ${ }_{3}<0.001^{*}$ & & \\
\hline
\end{tabular}

F: F for ANOVA test, Pairwise comparison bet. Each of 2 groups was done using Post Hoc Test (Tukey)

$\mathrm{p}_{1}$ : $\mathrm{p}$ value for comparing between Healthy and Gingivitis

$\mathrm{p}_{2}$ : $\mathrm{p}$ value for comparing between Healthy and Periodontitis (Before)

$\mathrm{p}_{3}$ : $\mathrm{p}$ value for comparing between Gingivitis and Periodontitis (Before)

*: Statistically significant at $\mathrm{p} \leq 0.05$ 
TABLE (1C) Summarizes comparison between Healthy and Periodontitis groups according to AST: there was a statistically non-significant difference in mean AST in the two groups after SRP. Periodontitis group after SRP showed mean AST 62.10 \pm 23.83 and Healthy group showed 52.95 \pm 13.39 . (Enzymatic activity of Periodontitis group after SRP got almost similar to Healthy group).

\begin{tabular}{|c|c|c|c|}
\hline \multirow{2}{*}{\begin{tabular}{c}
\multirow{2}{*}{$\begin{array}{c}\text { Healthy } \\
(\mathbf{n}=\mathbf{2 0})\end{array}$} \\
\cline { 3 - 4 }
\end{tabular}} & $\begin{array}{c}\text { Before } \\
(\mathbf{n = 2 0 )}\end{array}$ & $\begin{array}{c}\text { After } \\
(\mathbf{n = 2 0})\end{array}$ \\
\hline AST & $52.95 \pm 13.39$ & $195.35 \pm 46.86$ & $62.10 \pm 23.83$ \\
\hline $\mathrm{p}_{1}$ & & $<0.001^{*}$ & 0.145 \\
\hline $\mathrm{p}_{2}$ & & \multicolumn{2}{|c|}{$<0.001^{*}$} \\
\hline
\end{tabular}

$\mathrm{p}_{1}$ : $\mathrm{p}$ value for Student t-test for comparing between Healthy and Periodontitis

$\mathrm{p}_{2}: \mathrm{p}$ value for Paired t-test for comparing between Before and After

*: Statistically significant at $\mathrm{p} \leq 0.05$

\section{ALT}

TABLE (2A) summarizes descriptive statistics of ALT in each studied group. Healthy group showed mean ALT 23.35 \pm 7.36 while Gingivitis group showed $85.55 \pm 36.93$ and Periodontitis group showed $131.30 \pm 35.12$ before treatment and $28.75 \pm 7.27$ after treatment.

\begin{tabular}{|c|c|c|c|c|c|c|}
\hline \multirow{3}{*}{ Groups } & \multirow{3}{*}{$\mathbf{N}$} & \multicolumn{5}{|c|}{ ALT } \\
\hline & & \multirow{2}{*}{ Min. } & \multirow{2}{*}{ Max. } & \multirow{2}{*}{ Mean \pm SD } & \multicolumn{2}{|c|}{$95 \%$ CI } \\
\hline & & & & & LL & UL \\
\hline \multicolumn{2}{|c|}{ Healthy $(n=20)$} & 9.0 & 36.0 & $23.35 \pm 7.36$ & 19.91 & 26.79 \\
\hline \multicolumn{2}{|c|}{ Gingivitis $(n=20)$} & 22.0 & 160.0 & $85.55 \pm 36.93$ & 68.27 & 102.83 \\
\hline \multirow{2}{*}{ Periodontitis $(n=20)$} & Before & 89.0 & 189.0 & $131.30 \pm 35.12$ & 114.86 & 147.74 \\
\hline & After & 17.0 & 42.0 & $28.75 \pm 7.27$ & 25.35 & 32.15 \\
\hline
\end{tabular}

TABLE (2B) Summarizes comparison between the three groups according to ALT: there was a statistically significant difference in mean ALT in the three groups. Periodontitis group showed a higher mean ALT $131.30 \pm 35.12$ while Gingivitis group showed $85.55 \pm 36.93$ and Healthy group showed 23.35 \pm 7.36 .

\begin{tabular}{|c|c|c|c|c|c|}
\hline & $\begin{array}{c}\text { Healthy } \\
(\mathbf{n = 2 0})\end{array}$ & $\begin{array}{c}\text { Gingivitis } \\
(\mathbf{n = 2 0})\end{array}$ & $\begin{array}{c}\text { Periodontitis (Before) } \\
(\mathbf{n = 2 0 )}\end{array}$ & F \\
\hline ALT & $23.35 \pm 7.36$ & $85.55 \pm 36.93$ & $131.30 \pm 35.12$ & $66.433^{*}$ & $<0.001^{*}$ \\
\hline Sig. bet. grps & \multicolumn{3}{|c|}{$\mathrm{p}_{1}<0.001^{*}, \mathrm{p}_{2}<0.001^{*}, \mathrm{p}_{3}<0.001^{*}$} & & \\
\hline
\end{tabular}

F: F for ANOVA test, Pairwise comparison bet. each 2 groups was done using Post Hoc Test (Tukey)

$\mathrm{p}_{1}$ : $\mathrm{p}$ value for comparing between Healthy and Gingivitis

$\mathrm{p}_{2}: \mathrm{p}$ value for comparing between Healthy and Periodontitis (Before)

$\mathrm{p}_{3}: \mathrm{p}$ value for comparing between Gingivitis and Periodontitis (Before)

*: Statistically significant at $\mathrm{p} \leq 0.05$ 
TABLE (2C) Summarizes comparison between Healthy and Periodontitis groups according to ALT: there was a statistically non-significant difference in mean ALT in the two groups after SRP. Periodontitis group after SRP showed mean ALT 28.75 \pm 7.27 while Healthy group showed 23.35 \pm 7.36 .

\begin{tabular}{|c|c|c|c|}
\hline \multirow{2}{*}{$\begin{array}{c}\text { Healthy } \\
(\mathbf{n}=\mathbf{2 0})\end{array}$} & $\begin{array}{c}\text { Pefore } \\
(\mathbf{n = 2 0 )}\end{array}$ & $\begin{array}{c}\text { After } \\
(\mathbf{n}=\mathbf{2 0})\end{array}$ \\
\cline { 3 - 4 } & & $131.30 \pm 35.12$ & $28.75 \pm 7.27$ \\
\hline ALT & $23.35 \pm 7.36$ & $<0.001^{*}$ & 0.051 \\
\hline $\mathrm{p}_{1}$ & & \multicolumn{2}{|c|}{$<0.001^{*}$} \\
\hline $\mathrm{p}_{2}$ & & \multicolumn{2}{|c|}{} \\
\hline
\end{tabular}

$\mathrm{p}_{1}$ : $\mathrm{p}$ value for Student t-test for comparing between

Healthy and Periodontitis

$\mathrm{p}_{2}$ : $\mathrm{p}$ value for Paired t-test for comparing between Before and After

*: Statistically significant at $\mathrm{p} \leq 0.05$

\section{GGT}

TABLE (3A) summarizes descriptive statistics of GGT in each studied group. Healthy group showed mean of $5.70 \pm 1.63$. Gingivitis group showed mean of $18.45 \pm 3.94$ while Periodontitis group showed $46.25 \pm 18.06$ before treatment and $9.45 \pm 4.29$ after treatment.

\begin{tabular}{|c|c|c|c|c|c|c|}
\hline \multirow{3}{*}{ Groups } & \multirow{3}{*}{$\mathbf{N}$} & \multicolumn{5}{|c|}{ GGT } \\
\hline & & \multirow{2}{*}{ Min. } & \multirow{2}{*}{ Max. } & \multirow{2}{*}{ Mean \pm SD } & \multicolumn{2}{|c|}{$95 \% \mathrm{CI}$} \\
\hline & & & & & $\mathbf{L L}$ & UL \\
\hline \multicolumn{2}{|c|}{ Healthy $(n=20)$} & 3.0 & 8.0 & $5.70 \pm 1.63$ & 4.94 & 6.46 \\
\hline \multicolumn{2}{|c|}{ Gingivitis $(n=20)$} & 12.0 & 24.0 & $18.45 \pm 3.94$ & 16.61 & 20.29 \\
\hline \multirow{2}{*}{ Periodontitis $(n=20)$} & Before & 23.0 & 71.0 & $46.25 \pm 18.06$ & 37.80 & 54.70 \\
\hline & After & 3.0 & 16.0 & $9.45 \pm 4.29$ & 7.44 & 11.46 \\
\hline
\end{tabular}

TABLE (3B) summarizes comparison between the three groups according to GGT: there was a statistically significant difference in mean GGT in the three groups. Periodontitis group showed mean GGT of

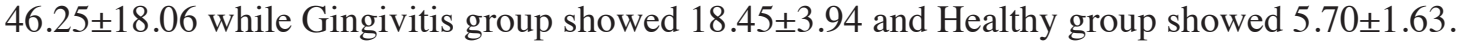

\begin{tabular}{|c|c|c|c|c|c|}
\hline & $\begin{array}{c}\text { Healthy } \\
(\mathbf{n = 2 0})\end{array}$ & $\begin{array}{c}\text { Gingivitis } \\
(\mathbf{n = 2 0})\end{array}$ & $\begin{array}{c}\text { Periodontitis (Before) } \\
(\mathbf{n = 2 0})\end{array}$ & F & P \\
\hline GGT & $5.70 \pm 1.63$ & $18.45 \pm 3.94$ & $46.25 \pm 18.06$ & $74.958^{*}$ & $<0.001^{*}$ \\
\hline Sig. bet. grps & \multicolumn{2}{|c|}{$\mathrm{p}_{1}=0.001^{*}, \mathrm{p}_{2}<0.001^{*}, \mathrm{p}_{3}<0.001^{*}$} & & \\
\hline
\end{tabular}

F: F for ANOVA test, Pairwise comparison bet. Each of 2 groups was done using Post Hoc Test (Tukey)

$\mathrm{p}_{1}$ : $\mathrm{p}$ value for comparing between Healthy and Gingivitis

$\mathrm{p}_{2}: \mathrm{p}$ value for comparing between Healthy and Periodontitis (Before)

$\mathrm{p}_{3}: \mathrm{p}$ value for comparing between Gingivitis and Periodontitis (Before)

*: Statistically significant at $\mathrm{p} \leq 0.05$ 
TABLE (3C) summarizes comparison between Healthy and Periodontitis groups according to GGT: there was a statistically non-significant difference in mean GGT in the two groups after therapy. Periodontitis

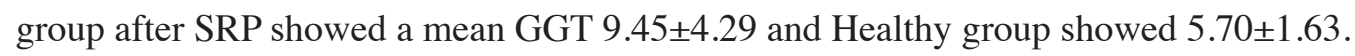

\begin{tabular}{|c|c|c|c|c|}
\hline & \multirow[b]{2}{*}{$\begin{array}{l}\text { Healthy } \\
(n=20)\end{array}$} & \multicolumn{2}{|c|}{ Periodontitis } & \multirow{5}{*}{$\begin{array}{l}\mathrm{p}_{1}: \mathrm{p} \text { value for Student } \mathrm{t} \text {-test for comparing between } \\
\text { Healthy and Periodontitis } \\
\mathrm{p}_{2}: \mathrm{p} \text { value for Paired } \mathrm{t} \text {-test for comparing between Be- } \\
\quad \text { fore and After } \\
* \text { : Statistically significant at } \mathrm{p} \leq 0.05\end{array}$} \\
\hline & & $\begin{array}{c}\text { Before } \\
(n=20)\end{array}$ & $\begin{array}{c}\text { After } \\
(n=20)\end{array}$ & \\
\hline GGT & $5.70 \pm 1.63$ & $46.25 \pm 18.06$ & $9.45 \pm 4.29$ & \\
\hline $\mathrm{p}_{1}$ & & $<0.001^{*}$ & 0.057 & \\
\hline $\mathrm{p}_{2}$ & & \multicolumn{2}{|c|}{$<0.001^{*}$} & \\
\hline
\end{tabular}

\section{LDH}

TABLE (4A) summarizes descriptive statistics of LDH in each studied group. Healthy group showed mean LDH of 176.25 \pm 19.97 , while Gingivitis group showed mean of $351.95 \pm 110.6$ and Periodontitis group showed $526.95 \pm 177.6$ before treatment and $411.30 \pm 158.8$ after treatment.

\begin{tabular}{|c|c|c|c|c|c|c|}
\hline \multirow{3}{*}{ Groups } & \multirow{3}{*}{$\mathrm{N}$} & \multicolumn{5}{|c|}{$\mathrm{LDH}$} \\
\hline & & \multirow{2}{*}{ Min. } & \multirow{2}{*}{ Max. } & \multirow{2}{*}{ Mean \pm SD } & \multicolumn{2}{|c|}{$95 \% \mathrm{CI}$} \\
\hline & & & & & LL & UL \\
\hline \multicolumn{2}{|c|}{ Healthy $(\mathrm{n}=20)$} & 144.0 & 208.0 & $176.25 \pm 19.97$ & 166.91 & 185.59 \\
\hline \multicolumn{2}{|c|}{ Gingivitis $(\mathrm{n}=20)$} & 178.0 & 732.0 & $351.95 \pm 110.6$ & 300.20 & 403.70 \\
\hline \multirow{2}{*}{ Periodontitis $(\mathrm{n}=20)$} & Before & 186.0 & 860.0 & $526.95 \pm 177.6$ & 443.82 & 610.08 \\
\hline & After & 117.0 & 706.0 & $411.30 \pm 158.8$ & 336.98 & 485.62 \\
\hline
\end{tabular}

TABLE (4B) summarizes comparison between the three groups according to LDH: there was a statistically significant difference in mean LDH in the three groups. Periodontitis group showed mean LDH of

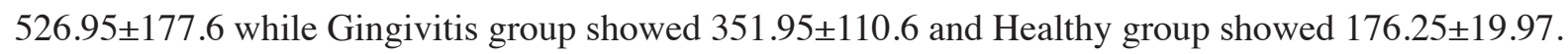

\begin{tabular}{|c|c|c|c|c|c|}
\hline & $\begin{array}{c}\text { Healthy } \\
(\mathbf{n = 2 0})\end{array}$ & $\begin{array}{c}\text { Gingivitis } \\
(\mathbf{n = 2 0 )}\end{array}$ & $\begin{array}{c}\text { Periodontitis (Before) } \\
(\mathbf{n}=\mathbf{2 0})\end{array}$ & F & P \\
\hline LDH & $176.25 \pm 19.97$ & $351.95 \pm 110.6$ & $526.95 \pm 177.6$ & $41.759^{*}$ & $<0.001^{*}$ \\
\hline Sig. bet. grps & \multicolumn{3}{|c|}{$\mathrm{p}_{1}<0.001^{*}, \mathrm{p}_{2}<0.001^{*}, \mathrm{p}_{3}<0.001^{*}$} & & \\
\hline
\end{tabular}

F: F for ANOVA test, Pairwise comparison bet. Each of 2 groups was done using Post Hoc Test (Tukey)

$\mathrm{p}_{1}: \mathrm{p}$ value for comparing between Healthy and Gingivitis

$\mathrm{p}_{2}: \mathrm{p}$ value for comparing between Healthy and Periodontitis (Before)

$\mathrm{p}_{3}: \mathrm{p}$ value for comparing between Gingivitis and Periodontitis (Before)

*: Statistically significant at $\mathrm{p} \leq 0.05$ 
TABLE (4C) summarizes comparison between Healthy and Periodontitis groups according to LDH: there was a statistically significant difference in mean LDH in the two groups after SRP. Periodontitis group after SRP showed mean LDH $411.30 \pm 158.8$ and Healthy group showed 176.25 \pm 19.97 . (Enzymatic activity of LDH did not decrease to a significant limit after therapy.)

\begin{tabular}{|c|c|c|c|}
\hline & \multirow{2}{*}{$\begin{array}{l}\text { Healthy } \\
(n=20)\end{array}$} & \multicolumn{2}{|l|}{ Periodontitis } \\
\hline & & $\begin{array}{l}\text { Before } \\
(\mathrm{n}=20)\end{array}$ & $\begin{array}{l}\text { After } \\
(\mathrm{n}=20)\end{array}$ \\
\hline LDH & $176.25 \pm 19.97$ & $526.95 \pm 177.6$ & $411.30 \pm 158.8$ \\
\hline $\mathrm{p}_{1}$ & & $<0.001^{*}$ & $<0.001^{*}$ \\
\hline $\mathrm{p}_{2}$ & & \multicolumn{2}{|l|}{$0.004^{*}$} \\
\hline
\end{tabular}

$\mathrm{p}_{1}$ : $\mathrm{p}$ value for Student t-test for comparing between Healthy and Periodontitis $\mathrm{p}_{2}$ : $\mathrm{p}$ value for Paired t-test for comparing between Before and After *: Statistically significant at $\mathrm{p} \leq 0.05$

\section{CK}

TABLE (5A) summarizes descriptive statistics of CK in each studied group. Healthy group showed mean CK of $11.35 \pm 3.53$ while Gingivitis group showed 21.40 \pm 7.55 and Periodontitis group showed $52.15 \pm 15.12$ before SRP and 15.40 \pm 1.98 after SRP.

\begin{tabular}{|c|c|c|c|c|c|c|}
\hline \multirow{3}{*}{ Groups } & \multirow{3}{*}{$\mathbf{N}$} & \multicolumn{5}{|c|}{ CK } \\
\hline & & \multirow{2}{*}{ Min. } & \multirow{2}{*}{ Max. } & \multirow{2}{*}{ Mean \pm SD } & \multicolumn{2}{|c|}{$95 \% \mathrm{CI}$} \\
\hline & & & & & $\mathbf{L L}$ & UL \\
\hline \multicolumn{2}{|c|}{ Healthy $(n=20)$} & 6.0 & 17.0 & $11.35 \pm 3.53$ & 9.70 & 13.00 \\
\hline \multicolumn{2}{|c|}{ Gingivitis $(n=20)$} & 11.0 & 34.0 & $21.40 \pm 7.55$ & 17.87 & 24.93 \\
\hline \multirow{2}{*}{ Periodontitis $(n=20)$} & Before & 25.0 & 73.0 & $52.15 \pm 15.12$ & 45.07 & 59.23 \\
\hline & After & 2.0 & 18.0 & $15.40 \pm 1.98$ & 4.47 & 6.33 \\
\hline
\end{tabular}

TABLE (5B) summarizes comparison between the three groups according to CK: there was a statistically significant difference in mean CK in the three groups. Periodontitis group showed mean CK $52.15 \pm 15.12$,

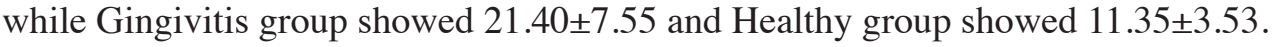

\begin{tabular}{|l|l|l|l|l|l|}
\hline & $\begin{array}{l}\text { Healthy } \\
(\mathbf{n = 2 0})\end{array}$ & $\begin{array}{l}\text { Gingivitis } \\
(\mathbf{n = 2 0})\end{array}$ & $\begin{array}{l}\text { Periodontitis (Before) } \\
(\mathbf{n = 2 0})\end{array}$ & $\mathbf{F}$ & $\mathbf{P}$ \\
\hline CK & $11.35 \pm 3.53$ & $21.40 \pm 7.55$ & $52.15 \pm 15.12$ & $90.950^{*}$ & $<0.001^{*}$ \\
\hline Sig. bet. grps & $\mathrm{p}_{1}=0.006^{*}, \mathrm{p}_{2}<0.001^{*}, \mathrm{p}_{3}<0.001^{*}$ & & \\
\hline
\end{tabular}

F: F for ANOVA test, Pairwise comparison bet. Each of 2 groups was done using Post Hoc Test (Tukey)

$\mathrm{p}_{1}$ : $\mathrm{p}$ value for comparing between Healthy and Gingivitis

$\mathrm{p}_{2}: \mathrm{p}$ value for comparing between Healthy and Periodontitis (Before)

$\mathrm{p}_{3}: \mathrm{p}$ value for comparing between Gingivitis and Periodontitis (Before)

*: Statistically significant at $\mathrm{p} \leq 0.05$ 
TABLE (5C) Summarizes comparison between Healthy and Periodontitis groups according to CK: there was a statistically non-significant difference in mean $\mathrm{CK}$ in the two groups after treatment. Periodontitis group after SRP showed mean CK $15.40 \pm 1.98$ and Healthy group showed 11.35 \pm 3.53 .

\begin{tabular}{|c|c|c|c|}
\hline & \multirow{2}{*}{$\begin{array}{l}\text { Healthy } \\
(n=20)\end{array}$} & \multicolumn{2}{|c|}{ Periodontitis } \\
\hline & & $\begin{array}{c}\text { Before } \\
(n=20)\end{array}$ & $\begin{array}{c}\text { After } \\
(n=20)\end{array}$ \\
\hline CK & $11.35 \pm 3.53$ & $52.15 \pm 15.12$ & $15.40 \pm 1.98$ \\
\hline $\mathrm{p}_{1}$ & & $<0.001^{*}$ & 0.065 \\
\hline $\mathrm{p}_{2}$ & & \multicolumn{2}{|c|}{$<0.001^{*}$} \\
\hline
\end{tabular}

$\mathrm{p}_{1}$ : $\mathrm{p}$ value for Student $\mathbf{t}$-test for comparing between

Healthy and Periodontitis

$\mathrm{p}_{2}$ : $\mathrm{p}$ value for Paired t-test for comparing between Be-

fore and After

*: Statistically significant at $\mathrm{p} \leq 0.05$

\section{DISCUSSION}

In our study, we have found that all the five studied enzymes were elevated in periodontal diseases more than people with healthy oral conditions. One of the studied enzymes was LDH. LDH is a ubiquitous enzyme that plays a significant role in the clinical diagnosis of pathologic processes.

In accordance with our results, a paper by Sornin et al. ${ }^{(10)}$ has been found referring to LDH activity in whole saliva in individuals with and without periodontal disease. In accordance with our present study, the results pointed out that the LDH activity value was higher in patients with periodontal disease in comparison to healthy individuals what can be an excellent candidate in the possible function for epidemiological biomarker of this disease.

Also coinciding with our results, Smith et al. (11) have shown that LDH activity is higher in subjects with increased probing depth (PD) than in individuals with normal PD. Furthermore Atici et al.
(12) have shown that the progression of periodontal disease may be associated with the level of LDH but it deserves noting that their studies were on GCF.

Concerning AST and ALT, in accordance with our study, high levels were found in Japanese women with periodontitis ${ }^{(13)}$ and Indians ${ }^{(14)}$.Also coinciding with Yoshie et al. ${ }^{(15)}$ who proved the decrease in AST and ALT levels in patients undergoing scaling and root planing treatment. It showed that the presence and activity of these enzymes are significantly associated to periodontitis. The difference between these studies and our study is that they were applied to serum while our study has dealt with saliva.

AST and ALT are transaminases considered as gold standard biomarkers of liver damage with high sensitivity ${ }^{(16)}$ being found in several other tissues such as heart, muscle, kidney, lung, and brain ${ }^{(17)}$. Being biomarkers of liver injury, these transaminases can also contribute with periodontal evaluation due to an association between periodontal disease and liver alterations ${ }^{(18)}$.

That is to say: One of the ways to explain high levels of ALT and AST in periodontitis is to remember that periodontitis is an inflammatory disease that promotes host response with release of reactive oxygen species, such as free radical diffusion into the blood stream, and effects upon the liver.

Another explanation is that: The enzymes (CK, LDH, AST, ALT and GGT) are intracellular enzymes and can be proved in saliva, within some normal limits, as these enzymes are determined even in blood of healthy persons. However, if a periodontal tissue becomes sick, or its cells become damaged, due to edema or destruction of a cellular membrane, i.e. of a cell as a whole, these intracellular enzymes are increasingly being released into the gingival crevicular fluid and then into saliva where their activity can be measured. Due to this, these enzymes can be biochemical markers of the functional condition of periodontal tissues ${ }^{(19)}$. 
In other words, these intracellular enzymes are included in metabolic processes of cells and they are mostly present in cells of soft tissues. They are indicators of a higher level of cellular damage and their increased activity in gingival crevicular fluid and saliva is a consequence of their increased release from the damaged cells of soft tissues of periodontium and a reflection of metabolic changes in the inflamed gingiva ${ }^{(20)}$.

Specifically, aspartate aminotransferase (AST) previously termed as glutamic oxaloacetate transferase (GOT) has been proven via our study coinciding with other studies e.g. Shimada et al. (21) and Siddique et al. ${ }^{(22)}$ to be a strong diagnostic indicator of periodontal inflammatory disease. Shimada et al. (21) suggested that AST levels may be a useful adjunct in the clinical assessment of periodontal disease, since AST level decreases when periodontal status improves. In his longitudinal study, Shimada et al. ${ }^{(21)}$ a statistically significant difference was reported between the reduction of probing depth at baseline and post-initial therapy coinciding with the level of AST.

Our results also coincide with Mehta et al. ${ }^{(23)}$ who found similar results as Shimada et al. concerning a positive relation between AST and periodontal diseases. We also have shown that there is a statistically significant correlation between mean periodontal probing depth (PPD) and the AST levels in Saliva at baseline (0-weeks) suggesting that during the diseased state, as the mean PPD increases, the mean AST levels in saliva also increase. A highly significant correlation also exists between mean PPD and the AST levels in saliva after 3-weeks of initial therapy suggesting that even after initial therapy, as the mean PPD decreases, the mean AST levels in saliva also decreases.

Over all, our present study resulted that levels of AST in saliva strongly correlate with periodontal disease and also correlate with the traditional clinical indices.
As a result of our study salivary AST level of $\geq 71 \mathrm{U} / \mathrm{L}$ has been suggested as the most suitable cut-off point to distinguish individuals at risk and most likely to progress gingivitis and periodontitis. AST level $\geq 115 \mathrm{U} / \mathrm{L}$ has the best positive predictive power to distinguish periodontitis from gingivitis.

Agreeing with Persson et al. ${ }^{(24)}$, we have demonstrated that AST levels can be used to assess the presence and extent of periodontal inflammation. Also agreeing with Magnusson et al. ${ }^{(25)}$ who concluded that the outcome of the test is an effective objective measure distinguishing between diseased sites and non-diseased sites using GCF when evaluated both prior to and following application of therapy.

We have found that the increased activity of certain tissue enzymes in periodontal disease can be proved in saliva, mostly; as a reflection of pathological and metabolic changes in cells of periodontal tissues. The value of their activity can reflect the depth of pathological processes and damages of periodontal tissues, i.e. can show whether it is the matter of inflammation only or the destructive changes in soft tissues and bones have already commenced and can indicate the prognosis of the course of this disease.

Our study reported a significant increase in salivary GGT and CK levels in patients with periodontitis and gingivitis as compared to healthy controls. The levels of salivary GGT and CK were also found to significantly decrease following periodontal therapy. The mean difference in the pre-treatment and post-treatment values of GGT and CK was found to be statistically significant. These findings were in confirmation with the results obtained by Todorovic et al. ${ }^{(26)}$.

Finally, our results show that the AST, ALT, GGT, CK and LDH analyses can together provide an important epidemiological marker in periodontal disease; since they all showed a significant increase in the periodontitis group in comparison with gingivitis group and the healthy one, and interestingly 
decreased after SRP; which may be due to repair of the cells and preserving the endogenous enzymes inside in addition to resolution of inflammation. However, one of the problems that may hinder their entrance in the periodontal diagnosis is the low specificity of each test, yet the analysis of all these enzymatic tests together may decrease or inhibit this specificity bias.

\section{CONCLUSION}

- $\quad$ The activities of ALT, AST, GGT, LDH and CK enzymes were significantly increased in the saliva of patients with periodontal disease in relation to those of healthy condition, thus they can be used as a biological biomarker for progression of periodontal disease.

- This is probably a consequence of pathological processes in periodontal tissues where from these intracellular enzymes are increasingly released into the secretion which surrounds them - saliva.

- There was also an established correlation between AST and the value of the gingival index and probing depth.

- After periodontal treatment the activity of examined salivary enzymes was decreased, which is probably a result of periodontal tissues repair.

- Screening of periodontal disease by measuring salivary levels of ALT, AST, GGT, LDH and CK may be a feasible, simple and convenient approach that does not require expert examiners especially in mass screening events.

\section{REFERENCES}

1. Cutress T, Ainamo J, Sardo-Infirri J. The community periodontal index of treatment needs (CPITN) procedure for population groups and individuals. Inter dent J. 1987;37(4):222-33.

2. Lang NP, Tonetti MS. Periodontal diagnosis in treated periodontitis: why, when and how to use clinical parameters. J Clin Periodontol. 1996;23(3):240-50.
3. Page RC, Kornman KS. The pathogenesis of human periodontitis: an introduction. Periodontol 2000. 1997;14(1): $9-11$.

4. Goodson JM. Diagnosis of periodontitis by physical measurement: interpretation from episodic disease hypothesis. J Periodontol. 1992;63:373-82.

5. Imrey PB, Chilton NW. Design and analytic concepts for periodontal clinical trials. J Periodontol. 1992;63:1124-40.

6. Zhang L, Henson BS, Camargo PM, Wong DT. The clinical value of salivary biomarkers for periodontal disease. Periodontol 2000. 2009;51(1):25-37.

7. Korte DL, Kinney J. Personalized medicine: an update of salivary biomarkers for periodontal diseases. Periodontol 2000. 2016;70(1):26-37.

8. Pfaffe T, Cooper-White J, Beyerlein P, Kostner K, Punyadeera C. Diagnostic potential of saliva: current state and future applications. Clin Chem. 2011;57(5):675-87.

9. Löe H, Silness J. Periodontal disease in pregnancy I. Prevalence and severity. Acta Odontol Scand. 1963;21(6): 533-51.

10. Sornin C, Bousquet C, David P. Lactic acid formation in the oral cavity. Le Chirurgien-dentiste de France. 1986;56(356):63-7.

11. Smith QT, Au GS, Freese PL, Osborn JB, Stoltenberg JL. Five parameters of gingival crevicular fluid from eight surfaces in periodontal health and disease. J Periodontal Res. 1992;27(5):466-75.

12. Atici K, Yamalik N, Eratalay K, Etikán Í. Analysis of gingival crevicular fluid intracytoplasmic enzyme activity in patients with adult periodontitis and rapidly progressive periodontitis. A longitudinal study model with periodontal treatment. J Periodontol. 1998;69(10):1155-63.

13. Saito T, Shimazaki Y, Koga T, Tsuzuki M, Ohshima A. Relationship between periodontitis and hepatic condition in Japanese women. Journal of the International Academy of Periodontology. 2006;8(3):89-95.

14. Banu S, Jabir NR, Mohan R, Manjunath NC, Kamal MA, Vinod Kumar KR, et al. Correlation of Toll-like receptor 4 , interleukin-18, transaminases, and uric acid in patients with chronic periodontitis and healthy adults. J Periodontol. 2015;86(3):431-9.

15. Shimada Y, Komatsu Y, Ikezawa-Suzuki I, Tai H, Sugita $\mathrm{N}$, Yoshie $\mathrm{H}$. The effect of periodontal treatment on serum leptin, interleukin-6, and C-reactive protein. J Periodontol. 2010;81(8):1118-23. 
16. Schomaker S, Warner R, Bock J, Johnson K, Potter D, Van Winkle J, et al. Assessment of emerging biomarkers of liver injury in human subjects. Toxicol Sci. 2013;132(2):27683.

17. Scaglione S, Kliethermes S, Cao G, Shoham D, Durazo R, Luke A, et al. The epidemiology of cirrhosis in the United States. J Clin Gastroenterol. 2015;49(8):690-6.

18. Ekuni D, Mizutani S, Kojima A, Tomofuji T, Irie K, Azuma $\mathrm{T}$, et al. Relationship between increases in BMI and changes in periodontal status: a prospective cohort study. J Clin Periodontol. 2014;41(8):772-8.

19. NUMABE Y, HISANO A, KAMOI K, YOSHIE H, ITO $\mathrm{K}$, KURIHARA H. Analysis of saliva for periodontal diagnosis and monitoring. Dent Jpn (Tokyo). 2004;40:115-9.

20. Ozmeric N. Advances in periodontal disease markers. Clin Chim Acta. 2004;343(1-2):1-16.

21. Shimada K, Mizuno T, Ohshio K, Kamaga M, Murai S, Ito K. Analysis of aspartate aminotransferase in gingival crevicular fluid assessed by using PocketWatchTM: a longitudinal study with initial therapy. J Clin Periodontol. 2000;27(11):819-23.
22. Siddique S, Panchmal GS, Pullishery F. Aspartate Aminotransferase as a biomarker in periodontal disease: A comparative in vitro study. Saudi Journal of Oral Sciences. 2016;3(1):21.

23. Sheth TS, Verma SJ. Analysis of aspartate aminotransferase in gingival crevicular fluid: A study with initial therapy. J Indian Soc Periodontol. 2011;15(3):235.

24. Persson GR, DeRouen TA, Page RC. Relationship between levels of aspartate aminotransferase in gingival crevicularfluid and gingival inflammation. J Periodontal Res. 1990;25(1):17-24.

25. Magnussen I, Persson RG, Page C, DeRouen TA, Crawford JM, Cohen RL, et al. A multi-center clinical trial of a new chairside test in distinguishing between diseased and healthy periodontal sites. II. Association between site type and test outcome before and after therapy. J Periodontol. 1996;67(6):589-96.

26. Todorovic T, Dozic I, Barrero MV, Ljuskovic B, Pejovic J, Marjanovic M, et al. Salivary enzymes and periodontal disease. Medicina oral, patología oral y cirugía bucal Ed inglesa. 2006;11(2):4. 